\title{
The role of foraging (harvester) ants, Messor cephalotes, in land degradation in Meserani area Monduli District, Tanzania *Robert B. Kiunsi
}

\begin{abstract}
Meserani is a semi arid area in Monduli District in north east Tanzania that is prone to land degradation in terms of vegetation and soil degradation due to natural and anthropological factors. For a number of years the local community including extension officers had suspected that in certain locations of Meserani area bare lands, apart from grazing and farming activities were also created by grazing insects. The main objective of this paper was firstly, to identify the type of grazing insects that were creating bare lands, hence land degradation. Land degradation in this context is taken to mean the removal of herbaceous vegetation caver. Secondly, to determine the extent in which grazing insects are contributing to land degradation in the area. The harvester ants of species Messor cephalotes, Emmery were identified as the main insects that were foraging herbaceous vegetation cover thus creating bare lands in some of the locations in the study area. Areas with high intensity of human activities in terms of framing and grazing had more bare lands created by ants than the fallow or stony areas. Therefore in the Meserani harvester ants just like grazing or farming activities were contributing to land degradation through the creation of bare lands.
\end{abstract}

Key words: Messor cephalotes, grazing insects, land degradation, semi arid, overgrazing, and farming.

\section{Introduction}

nts are social insects belonging to family of formicidae and to the order Hymenoptera that have colonized almost every space of land. The exact number of ants species is not exactly known but estimates range from 10,000 to over 20,000 species of ants (http://www.greensmiths.com/ants.htm, http://www.lingolex.com/ants.htm, http://www.infowest.com/life/ants.htm). They live in colonies that range in size from few individuals to millions occupying vast space of land (http://en.wikipedia.org/wiki/Ant). Ants build different types of homes or nests that are used as nurseries, food storage and resting place. The nests of ants are made up of galleries and chambers that are found in underground, excavated under stones, logs decayed tree, hollow twigs or thorns (http://www.everythingabout.net/articles/biology /animals/arthropods/insects/ant/). Ants are termed as industrious although intensity of activities in a colon varies at certain times of a day. In tropics for the example the colonies are most active in the morning and late evenings when the temperatures are cool. During the cool times of the day the workers are most active in collecting and storing food (http://www.everythingabout.net/articles/biology /animals/arthropods/insects/ant/).

Ants feed on many different types of food that differ from species to species and depending on the feeding habits they can be classified as carnivorous, herbivorous or omnivorous.
Harvester ants for example, which are herbivorous, feed on and store in their nests, seeds of grasses, while the leaf cutter ants cut and carry large pieces of leaf to the nests. The army ants such as Eciton burchelli of the tropics are carnivorous nomadic species that feed on insects found along their travel path including the lizards, snakes, scorpions, and insects of all types.

(http://www.infoplease.com/ce6/sci/A0856629.h tml,

http://www.everything2.com/title/army+ants).

Ants are both beneficial and harmful to the environment. However, it is important to note that research on ants and environment has focused more on the beneficial rather than harmful effects of ants to the environment. The benefits for example include dispersal of seeds and the improvement of soils conditions in the vicinity of the nests. Wagner, Jones and Gordon, (2004) showed that soils within the vicinity of nests of harvester ant Pogonomynnex barbatus contain higher concentrations of organic matter, nitrogen and phosphorus than surrounding soils. This is due to the harvester ants collecting seed from the surrounding area and disposing them within the vicinity of the nests. According to Wilson (1971) ants can act as agents of seed dispersal. Dean and Yeaton (2008) on the other hand showed the impact of harvester ants in seed distribution in which more seedlings germinated in nest mounds than in inter-mount spaces. 
Driver ants are efficient exterminators of other more harmful insects found in homes and at the same they form and important component of diet for small mammals. An example of harmful effects of ants to environmental and humans includes invading and causing damage to buildings destroying crops and stinging human or in some cases even kill an animal (http://www.infoplease.com/ce6/sci/A0856629.h tml,http://www.everythingabout.net/articles/biol ogy/animals/arthropods/insects/ant/),

http://www.springerlink.com/content/g8x7287u5 $84 \mathrm{w} 2 \times 31 /)$.

Ants can also contribute to land degradation under certain environmental conditions due to their foraging activities that removes the vegetation cover within the proximity of nests. Land degradation in the broader context means as an undesirable changes in the state of land from productive to unproductive due to natural or human factors (Interim Secretariat, 1994; Kiunsi 2004; GEF, 2009). Land degradation has two main processes, those leading to removal of vegetation in terms of structural or species changes or sand soil degradation in terms of soil erosion and deterioration. Since vegetation cover protects the top soils from erosive agents, the removal of vegetation cover exposes the top soils to wind and water erosion agents. The Interim Secretariat (1994) defines land degradation both as a process that is vegetation or soil degradation and end result, meaning fall in land productivity.. This study confines it self more on land degradation process of the removal of vegetation cover, rather than soil degradation.

The study area is located in the southern part of Monduli District, in the Arusha Region of northeast Tanzania. The area is bordered by military land in north and west, Meserani Chini in the south and Arumeru District in the east. For many years the area has been occupied by the Maasai people, traditionally pastoralists. It is a semi arid area with an annual rainfall totals in varying from $600 \mathrm{~mm}$ to $700 \mathrm{~mm}$. It is a typical dryland area of the Rift Valley and drought occurrence is a common phenomenon in the area as reflected by inter-annual rainfall variability (Kiunsi and Meadows 2006). According to MDC (1977) and Kiunsi (2002) the physical characteristics of the area, especially terrain, geology and soils, are strongly influenced by tectonic activities and volcanism. Shallow soils of silty or silty clay texture dominate the area.
The land cover is dominated by fields and grasslands, followed by grasslands and bare land and gullies (Figure 1). A number of significant environmental and socio-economic changes are taking place in the area including population increase and change in land cover and land use. The most significant land use changes in recent years are the increase in agricultural activities especially small -scale farming.

The study area is prone to land degradation in terms of both soil and vegetation degradation as reflected by gullies and bare lands due to natural and anthropological factors. The natural factors include presence of erodable volcanic soils with high content of sodium (Kiunsi, 2002). The dryland conditions though not contributing directly to land degradation, makes it difficulty for the herbaceous vegetation cover to regenerate easily once is removed or is put under pressure. The anthropological factors contributing to land degradation include inappropriate farming activities in a semi arid area and overgrazing. However, based on field observations, discussions with the local communities, district extension staff and the NEMC report of 1993 certain locations in the village were bare due the presence of insects that foraged mainly on herbaceous materials. The local Communities argued that the removal of herbaceous vegetation in such areas was due to farming, overgrazing and foraging by insects. The local community and extension staff suspected the involvement of harvester termites. The main objective of the study was therefore to establish the type of insects that were creating of bare lands in such locations and to determine extent of removal of herbaceous vegetation cover. Hence, establishing extent in which grazing insects contributed to land degradation.

\section{Methodology}

The overall methodology can be dived into three main areas of literature review, field work for foraging insect study and insect identification. In literature review the focus was on land degradation on the Monduli District in general, using a number of studies already conducted in the area, including MDC (1997), Kiunsi (2002), Kiunsi and Meadows (2006). The study for foraging insects in the area that was conducted in August 2004 and also in 2005, based on the following approach. Three one-hectare plots were chosen to represent three habitat/landscape types in the area: a flat, seasonally flooded area (fallow), a flat non-flooded (farm), and an gently 
sloping, stony uncultivated area. In each plot bare patches caused by the insects were located, counted and their dimensions taken. In each patch the number of nests was recorded, together with the state of the nest (abandoned, dug out, or active). The insects were identified (preliminary identification).

Figure 1 Land cover for the study area

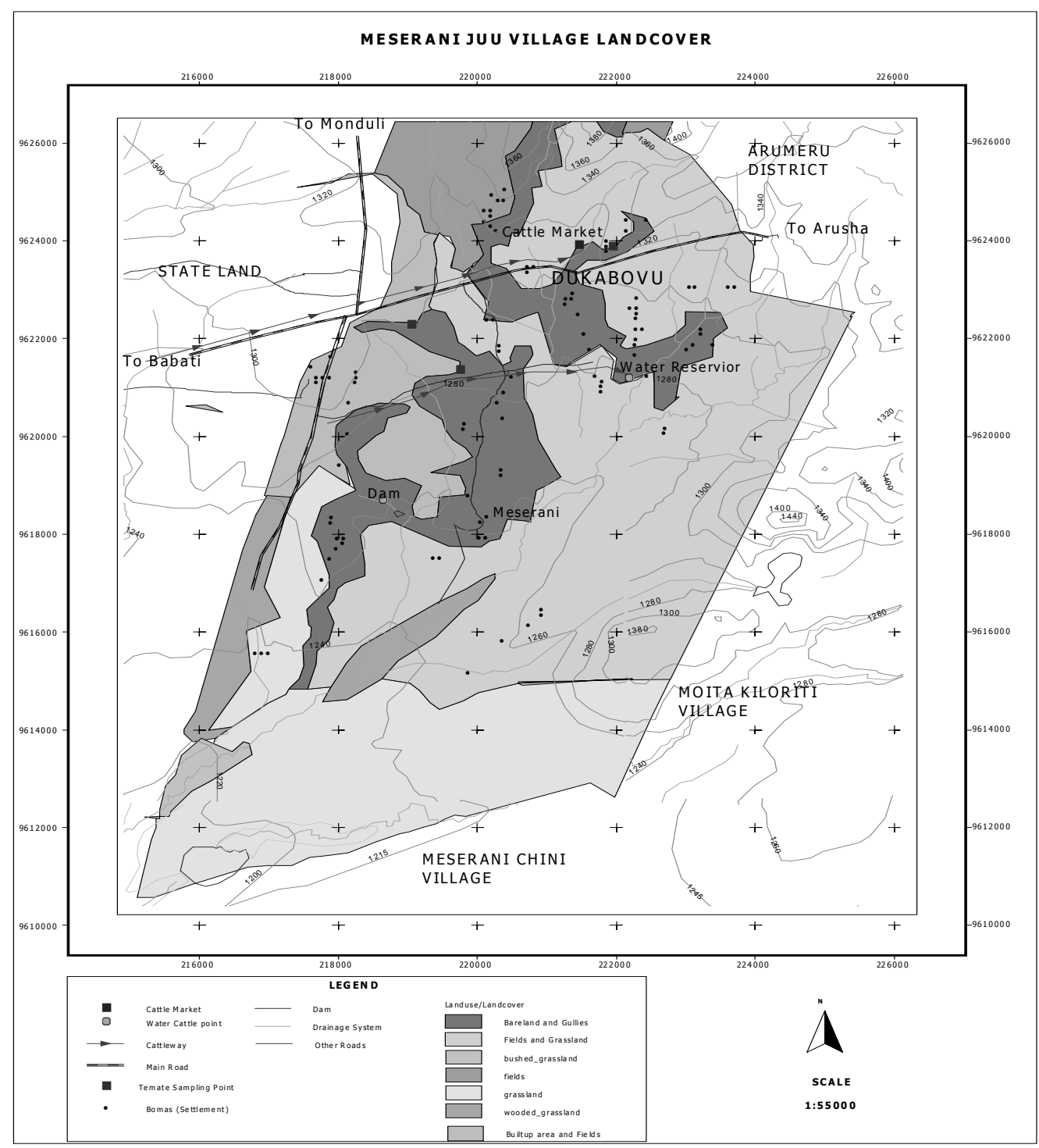

Source (Field work of 2004 and 2005)

Time of activity was observed from $0600 \mathrm{hrs}$ to 1800hrs. Pitfall traps were set to overnight to investigate night-active insects. The collected samples of insects were sent to the National Museums of Kenya for final identification.

\section{Results}

\section{Identification}

Two species of harvester ants were active in the study site. The first was identified as
Tetramorium sp. (family Formicidae, sub-family Myrmeciinae). This tiny ant (c. $3 \mathrm{~mm}$ long) did not produce extensive bare patches, and was excluded from further study. The second species was Messor cephalotes Emery. This was a species of large harvester ants that produced large oval bare areas around their nests, with long foraging trails leading into the surrounding areas. 
Number of patches, patch area, and nests

The number of patches in each of the three onehectare plots varied (mean $=5,6$, and 24 in the stony scrub, farm and fallow areas respectively). This difference was statistically significant $\left(\chi^{2}=19.404, p<0.001\right)$. The number of nests per patch ranged from 1 to 25 , with an average of 1.6, 4.2 and 4.9 nests per patch for the three respective sites. This was statistically significant (Kruskal-Wallis $H=9.404,0.01<\mathrm{p}<0.005$ ). Most of the nests were abandoned (previous year's), some were recently dug out (by anteaters or shrews?), and a few were active (where harvester ants were observed foraging) (see Table 1). The active patches were cleanly swept (bare of any vegetation), while the abandoned ones showed varying degrees of regeneration of grasses. Plate 1 shows a nest in fallow areas surrounded by bare land and Plate 2 shows ants nests in sloping stony uncultivated area surrounded by bare patches. Mean patch area was 20.4, 49.8 and 63.1 square metres for the three areas respectively. This showed no significant variation (Kruskal-Wallis $H=3.846$, $\mathrm{p}>0.1)$. The total cleared area per hectare for the three locations was 102.1 (1.02\%), 298.5 $(2.985 \%)$ and $1513.3(15.13 \%)$ square metres respectively. Many patch areas had more than one nest. In some patches some nests were active while others were old abandoned nests. The patch area per nest was extremely variable, ranging from 1.5 to $47 \mathrm{~m}^{2}$ per nest (mean $=11.27$ $\mathrm{m}^{2}$ ) in all three areas combined. Between sites patch area per nest showed no statistical difference (Kruskal-Wallis $H=1.506, \mathrm{p}>0.4$ ).

The number of active nests and recently dug-up nests (present season) was 3, 0 and 5 in the three locations respectively. At the last site there were also freshly dug out nests (where live ants could still be seen), showing that this site had the highest activity of Messor cephalotes. The ants were active from early in the morning to about $1100 \mathrm{hrs}$, and late in the evening, when the temperature was low. At noon and during the night there was no activity. The ants were observed carrying seed-bearing panicles of grasses and herbs into their nests.

\section{Discussion}

The present study confirmed a significant distribution of harvester ants (Messor cephalotes) in the study area. Messor cephalotes (emery) is a very distinctive East African species found in Ethiopia at Ganale Gudda, in Keya at Nakuru, Lake Ngunga, kericho, and Kajiado and in Tanzania in Arusha (http://www.archive.org/stream/ants_06439/ants _06439_djvu.txt). The Messor cephalotes and not termites are responsible for the creation of bare lands in some locations of the study area due to their feeding habits. Areas cleared by these ants ranged from about $1 \%$ in the stony scrub area to above $15 \%$ in the farmed area. This is comparable to findings elsewhere in the world. In the United States, for example, it has been estimated that harvester ants of the species Pogonomyrmex spp. Leave bare an area of about $6 \%$ of the rangelands (Killough and LeSueur, 1953). According to Hill (1975), harvester ants Messor barbarus can cause a grazing loss to the magnitude of $10-20 \%$ in some areas. In addition to clearing vegetation around their nests, harvester ants also forage for grass seeds and seeds from other plants over a wide area, covering as much as $30 \%$ of the total area of rangelands (Stoddart et al., 1975). This may contribute, on a longer time-scale, to the loss of the seeded area, hence retarding regeneration of the rangelands.

In this study, it was clear that farmed area, which had a higher human activities and livestock density, was affected more by harvester ants compared to fallow areas and open stony scrub areas. This is contrary to the assertion by Whitford et al. (1999) that they found no significant difference in the activity of harvester ants between disturbed and undisturbed sites in the US. This may be explained that the US study involved many species of ants, while the present study deals specifically with one species of harvester ants.

\section{Conclusions}

It a an established fact that Meserani area is prone to land degradation in terms of vegetation and soil degradation due to natural and anthropological factors. Harvester ants (Messor cephalotes) are contributing to land degradation in the area through the creation of the bare lands. It can be argued that the bare lands created by the ants in the area are more visible due to a combination of environmental and anthropological factors. The environmental factors include the semi arid conditions, which has led the area to be dominated by herbaceous vegetation cover and does not easily regenerate when degraded or is put under pressure. The anthropological factors of poor farming and grazing strategies, which degrade the already poor grass cover in the area. As a result of this when the herbaceous vegetation is removed 
either by ants or human activities it recovery is slow and when the same process is repeated in

\section{References}

Dean W.R. J. and Yeaton R. I. (2008) The importance of harvester and Messor capencis nest -mounds as germination sites in the southern Karoo, South Africa. African Journal of Ecology. Volume 30 no.4 pp 335-345

Global Environmental Facility (2009) Investing in Land Stewardship. GEFs efforts to combat land degradation and desertification globally.

Hill, D. (1975) Agricultural Insects of the tropics \& their Control. Cambridge University Press, Cambridge.

Killough, J.R. and LeSueur, H. (1953) The red harvester ant. Our Public Lands 3, 4-14.

Kiunsi, R. B. (2002) The development and application of a comprehensive land degradation assessment in the Monduli District, Tanzania. PhD Thesis, University of Cape Town, Republic of South Africa

Kiunsi, R. B. and M.E. Meadows (2006) Assessing land degradation in the Monduli District, Northern Tanzania. Land degradation and Development 17:509-525

Monduli District Council (1997) Planning for a better environment In the Monduli Distrcit Netherlands Economic Institute. The Hague

NEMC (1993) Baseline mapping for monitoring of desertification in the Monduli area, Arusha, Tanzania. National Environmental Management Council Tanzania

Stoddart, L.A., Smith, A.D. and Box, T.W. (1975) Range Management, Third Edition. McGraw-Hill, New York. the following year the bare lands in the area become even more pronounced.

Wagner, D., Jones, B. J and Gordon D. M (2004) Development of harvester ant colonies alters soil chemistry. Soil Biology and Biochemistry Vol.36 no 5 Ppp 797-804

Whitford W.G., Van Zee J., Nash M.S., Smith W.E. and Herrick J.E. (1999) Ants as Indicators of exposure to environmental stressors in North American desert grasslands. Environmental Monitoring and Assessment 54, 143-171.

Wilson, E.O. (1971) The Insect Societies. Harvard University Press, Cambridge, Massachusetts and London.

http://www.archive.org/stream/ants_06439/ants_ 06439_djvu.txt.

http://www.greensmiths.com/ants.htm, http://www.lingolex.com/ants.htm, http://www.infowest.com/life/ants.htm) http://en.wikipedia.org/wiki/Ant http://www.everythingabout.net/articles/biology/ animals/arthropods/insects/ant/ http://www.everythingabout.net/articles/biology/ animals/arthropods/insects/ant/ (http://www.infoplease.com/ce6/sci/A0856629.h tml, http://www.everything2.com/title/army+ants http://www.infoplease.com/ce6/sci/A0856629.ht $\mathrm{ml}$,http://www.everythingabout.net/articles/biolo gy/animals/arthropods/insects/ant/),

http://www.springerlink.com/content/g8x7287u5 $84 \mathrm{w} 2 \times 31 /$

http://www.archive.org/stream/ants_06439/ants_ 06439_djvu.txt

\section{Acknowledgement}

I would like to acknowledge the following for facilitating this research. Sida/Sarec for funding the project, Dr Brundo Nyundo of Botany Department University of Dar es Salaam for his assistance during the field work survey, and the local communities and extension officers in the Monduli District. 
Plate no 1 Nest surrounded by bare land in fallow land

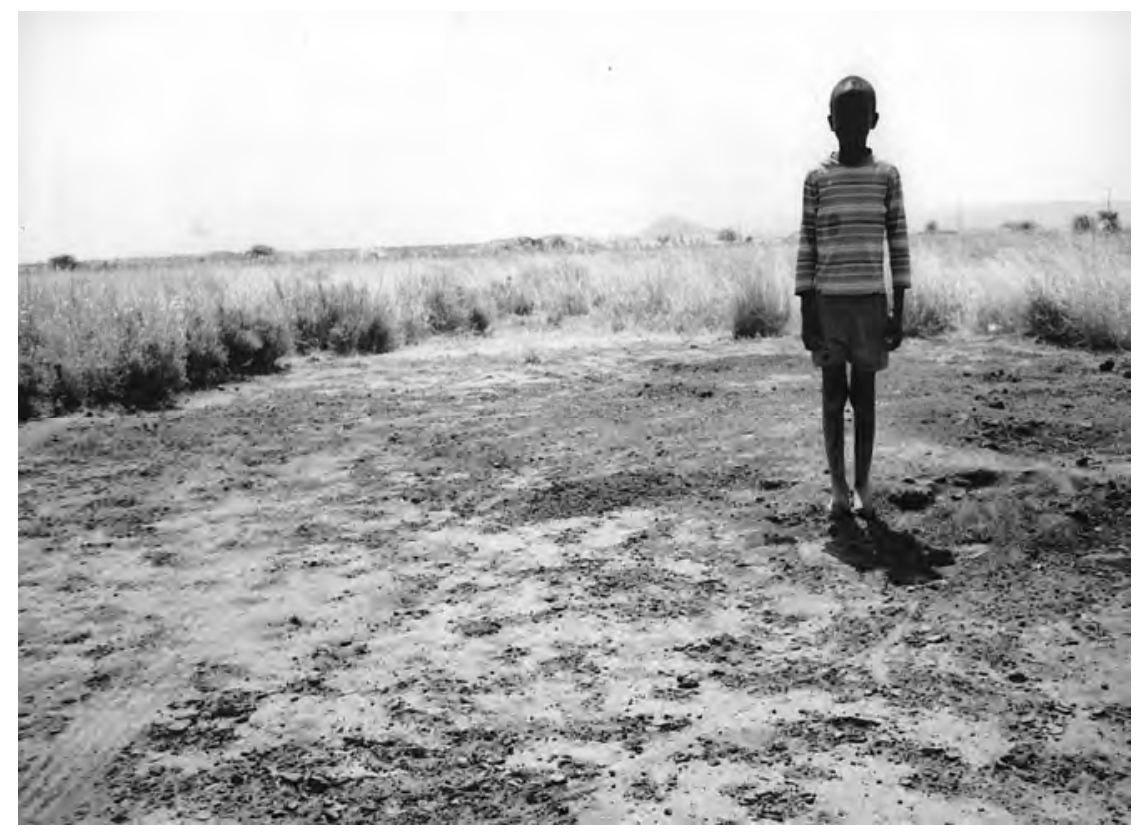

Plate No 2 an ant nest surrounded by bare land in the sloping and stony area, adjacent to the main road

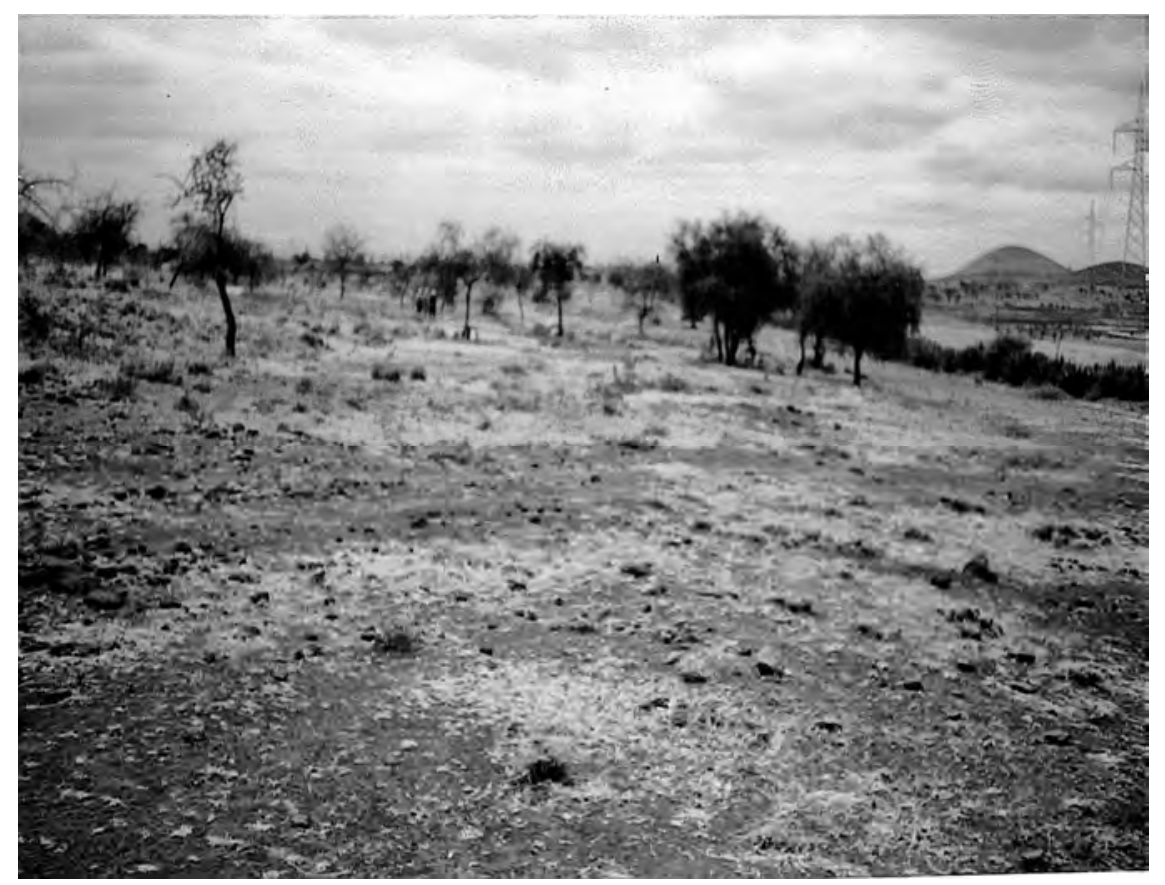


Table 1 The cleared patches created by Messor cephalotes, with the number and condition of nests in each area. $(1=$ stony scrub, $2=$ fallow, $3=$ farm $)$

\begin{tabular}{|c|c|c|c|c|c|}
\hline Site & $\begin{array}{l}\text { Patch } \\
\text { length (m) }\end{array}$ & $\begin{array}{l}\text { Patch } \\
\text { width (m) }\end{array}$ & $\begin{array}{l}\text { Patch Area } \\
\left(\mathbf{m}^{2}\right)^{*}\end{array}$ & $\begin{array}{l}\text { Number of } \\
\text { nests }\end{array}$ & $\begin{array}{l}\text { State of } \\
\text { nests }\end{array}$ \\
\hline \multirow{5}{*}{1 (stony scrub) area } & 2 & 2 & 3.1429 & 2 & Active \\
\hline & 3 & 2 & 4.7143 & 2 & Abandoned \\
\hline & 8 & 7 & 44.0000 & 2 & 1 Active \\
\hline & 2 & 2 & 3.1429 & 1 & Abandoned \\
\hline & 10 & 6 & 47.1429 & 1 & Active \\
\hline Sub-total & 25.0000 & 19.0000 & 102.1429 & 8.0000 & \\
\hline Average & 5.0000 & 3.8000 & 20.4286 & 1.6000 & \\
\hline \multirow[t]{24}{*}{2 Fallow area } & \begin{tabular}{|l|}
7 \\
\end{tabular} & 4 & 22.0000 & 4 & Abandoned \\
\hline & 9 & 9 & 63.6429 & 3 & Abandoned \\
\hline & 5 & 4 & 15.7143 & 2 & Abandoned \\
\hline & 3 & 2 & 4.7143 & 2 & Abandoned \\
\hline & 15 & 7 & 82.5000 & 12 & Abandoned \\
\hline & 4 & 3 & 9.4286 & 3 & Abandoned \\
\hline & 6 & 4 & 18.8571 & 2 & Abandoned \\
\hline & 5 & 4 & 15.7143 & 5 & Abandoned \\
\hline & 15 & 13 & 153.2143 & 6 & $\begin{array}{l}\text { Dug out, } 1 \\
\text { active }\end{array}$ \\
\hline & 2 & 1 & 1.5714 & 1 & Abandoned \\
\hline & 7 & 3 & 16.5000 & 3 & Abandoned \\
\hline & 5 & 5 & 19.6429 & 3 & Abandoned \\
\hline & 7 & 5 & 27.5000 & 3 & Abandoned \\
\hline & 10 & 5 & 39.2857 & 3 & Abandoned \\
\hline & \begin{tabular}{|l|}
7 \\
\end{tabular} & 6 & 33.0000 & 4 & Abandoned \\
\hline & 8 & 6 & 37.7143 & 2 & Abandoned \\
\hline & 3 & 3 & 7.0714 & 2 & Abandoned \\
\hline & 48 & 16 & 603.4286 & 25 & Abandoned \\
\hline & 13 & 7 & 71.5000 & 8 & Abandoned \\
\hline & 18 & 8 & 113.1429 & 5 & Abandoned \\
\hline & 12 & 6 & 56.5714 & 4 & Abandoned \\
\hline & 4 & 4 & 12.5714 & 2 & Abandoned \\
\hline & 8 & 6 & 37.7143 & 9 & Abandoned \\
\hline & 8 & 8 & 50.2857 & 5 & 2 Active \\
\hline Sub-total & 229 & 139 & 1513.2857 & 118 & \\
\hline Average & 9.5417 & 5.7917 & 63.0536 & 4.9167 & \\
\hline \multirow[t]{6}{*}{3 Farm area } & 12 & 9 & 84.8571 & 3 & Dug out \\
\hline & 9 & 7 & 49.5000 & 4 & Dug out \\
\hline & 5 & 4 & 15.7143 & 4 & Dug out \\
\hline & 6 & 6 & 28.2857 & 3 & Dug out \\
\hline & 18 & 4 & 56.5714 & 6 & Dug out \\
\hline & 9 & 9 & 63.6429 & 5 & Dug out \\
\hline Sub-total & 59 & 39 & 298.5714 & 25 & \\
\hline Average & \begin{tabular}{|l|}
9.8333 \\
\end{tabular} & 6.5000 & 49.7619 & 4.1667 & \\
\hline TOTAL & 313 & 197 & 1914.0000 & 151 & \\
\hline AVERAGE & \begin{tabular}{|l|}
8.9429 \\
\end{tabular} & 5.6286 & 54.6857 & 4.3143 & \\
\hline
\end{tabular}

Area is approximate: calculated for an ellipse $(\mathrm{A}=\pi .1 / 2 \mathrm{~L} .1 / 2 \mathrm{~W})$ 